\title{
A Dopamine DI Receptor-Dependent $\beta$-Arrestin Signaling Complex Potentially Regulates Morphine-Induced Psychomotor Activation but not Reward in Mice
}

\author{
Nikhil M Urs', Tanya L Daigle' and Marc G Caron*, 1,2,3 \\ 'Department of Cell Biology, Duke University, Durham, NC, USA; ${ }^{2}$ Department of Medicine, Duke University, Durham, NC, USA; ${ }^{3}$ Department of \\ Neurobiology, Duke University, Durham, NC, USA
}

\begin{abstract}
Morphine is a widely used analgesic in humans that is associated with multiple untoward effects, such as addiction and physical dependence. In rodent models, morphine also induces locomotor activity. These effects likely involve functionally selective mechanisms. Indeed, $\mathrm{G}$ protein-coupled receptor desensitization and adaptor protein $\beta$-arrestin 2 ( $\beta$ arr2) through its interaction with the $\mu$-opioid receptor regulates the analgesic but not the rewarding properties of morphine. However, $\beta$ arr2 is also required for morphine-induced locomotor activity in mice, but the exact cellular and molecular mechanisms that mediate this arrestin-dependent behavior are not understood. In this study, we show that $\beta$ arr2 is required for morphine-induced locomotor activity in a dopamine DI receptor (DIR)dependent manner and that a $\beta$ arr2/phospho-ERK ( $\beta$ arr2/pERK) signaling complex may mediate this behavior. Systemic administration of SL327, an MEK inhibitor, inhibits morphine-induced locomotion in wild-type mice in a dose-dependent manner. Acute morphine administration to mice promotes the formation of a $\beta$ arr2/pERK signaling complex. Morphine-induced locomotor activity and formation of the Barr2/pERK signaling complex is blunted in DIR knockout (DI-KO) mice and is presumably independent of D2 dopamine receptors. However, DIRs are not required for morphine-induced reward as DI-KO mice show the same conditioned place preference for morphine as do control mice. Taken together, these results suggest a potential role for a DIR-dependent $\beta$ arr $2 / p E R K$ signaling complex in selectively mediating the locomotor-stimulating but not the rewarding properties of morphine.

Neuropsychopharmacology (20II) 36, 55I-558; doi: I0.1038/npp.20 I0. I86; published online 27 October 2010
\end{abstract}

Keywords: morphine; locomotor activity; reward; dopamine receptors; $\beta$-arrestins; ERK

\section{INTRODUCTION}

Morphine binds to and activates $\mu$-opioid $\mathrm{G}$ proteincoupled receptors (GPCRs) in the brain and the spinal cord (Sora et al, 1997). In addition to its anti-nociceptive properties, morphine is also addictive, thereby complicating its usage (von Zastrow, 2004). The addictive properties of morphine have been attributed to its ability to activate $\mu$-opioid receptors on midbrain GABAergic interneurons, leading to a disinhibition of dopamine (DA) neurons in the ventral tegmental area, thus resulting in increased DA release in the dorsal and ventral striatum (Di Chiara and Imperato, 1988a, b; Johnson and North, 1992). DA released in the striatum activates GPCRs on medium spiny neurons (MSNs) belonging to the D1 and D2 family of dopamine receptors and can regulate various behaviors, such as reward, locomotion, and cognition (Missale et al, 1998).

*Correspondence: Dr MG Caron, Department of Cell Biology, Duke University Medical Center, Durham NC 277I0, USA, Tel: + I919684 5433, Fax: + I 919 68I 864I, E-mail: caron002@mc.duke.edu Received 29 July 2010; revised 13 September 2010; accepted 14 September 2010
GPCR signaling in the brain is terminated, at least in part, by a process termed 'desensitization' and is mediated by the concerted action of GPCR kinases (GRKs) and $\beta$-arrestins (Gainetdinov et al, 2004). In addition to desensitization, $\beta$-arrestins mediate the internalization of receptors and have also been shown to promote signaling through their ability to scaffold signaling molecules (Ferguson et al, 1996; Lefkowitz and Shenoy, 2005). The desensitization properties of $\beta$-arrestins are important for morphine-induced antinociception but not for tolerance or reward in mice (Bohn et al, 1999, 2002, 2003). In addition to anti-nociception, morphine also stimulates hyperlocomotor activity in mice in a dose-dependent manner (Bohn et al, 2003), and chronic morphine administration induces locomotor sensitization, which is considered to be implicated in drug addiction (Becker et al, 2001). The arrestin-dependent molecular mechanisms that regulate the manifestation of this hyperlocomotor behavior are unknown. Previous studies have implicated the cAMP/PKA/DARPP-32 signaling pathway as a potential mediator of the locomotor-stimulating effects of morphine in mice (Borgkvist et al, 2007). Although there are significant changes in DARPP-32 phosphorylation after acute morphine administration, the hyperlocomotor activity 
observed in DARPP-32 knockout (KO) or DARPP-32 T34A mice is not completely abolished, suggesting that additional signaling pathways might have a role in the manifestation of this behavior. Interestingly, locomotor activation to drugs of abuse such as amphetamine and morphine, but not cocaine and PCP, are blunted in $\beta$-arrestin $2 \mathrm{KO}$ ( $\beta$ arr2-KO) mice, suggesting a role for $\beta$-arrestin signaling complexes in mediating the behavioral effects of certain drugs (Beaulieu et al, 2005; Bohn et al, 2003) (T. Daigle, unpublished observations). Although $\beta$ arr2 is required for morphineinduced locomotor activation but not for its rewarding properties, the biochemical mechanisms and the role of different dopamine receptors that regulate this behavior are not known.

In this study, we used a combination of genetic mouse models and biochemical techniques to investigate the role of $\beta$-arrestin-dependent signaling in the manifestation of morphine-induced locomotor activity in mice and the potential molecular determinants. Our study suggests that a $\beta$ arr2/phospho-ERK ( $\beta$ arr2/pERK) signaling complex through the activation of the dopamine D1 receptor (D1R) may mediate the locomotor-enhancing action of morphine but not its rewarding properties.

\section{MATERIALS AND METHODS}

\section{Animals and Drugs}

All mouse studies were conducted in accordance with the $\mathrm{NIH}$ guidelines for animal care and use and with an approved animal protocol from the Duke University Animal Care and Use Committee. Generation of the dopamine transporter KO (DAT-KO), $\beta$ arr2-KO, $\beta$ arr1-KO, dopamine receptor $1 \mathrm{KO}$ (D1-KO), and dopamine receptor $2 \mathrm{KO}$ (D2-KO) mice and GSK3 $\beta+1-$ mice have been described previously (Bohn et al, 2003; Conner et al, 1997; Drago et al, 1994; Giros et al, 1996; Hoeflich et al, 2000; Kelly et al, 1997). Experimental mice were obtained by crossing heterozygotes to obtain wild-type (WT) and KO littermates. For biochemical and behavioral experiments with small molecule inhibitors, WT C57Bl/6J mice (The Jackson Laboratory, Bar Harbor, ME) were used. All mice were housed at a maximum of five per cage, provided with food and water ad libitum, and tested at 12-20 weeks of age. Mice were age and gender matched, and all experiments were conducted in drug-naive animals. Morphine sulfate, raclopride, and SCH23390 were purchased from Sigma (St Louis, MO) and freshly prepared in saline (Sal); TDZD (GSK3 inhibitor) and SL327 (MEK inhibitor) were purchased from Tocris Biosciences (Ellisville, MO), were dissolved in minimal Tween-20, and brought up to volume with distilled water. All drugs were injected at a volume of $10 \mu \mathrm{l} / \mathrm{g}$ animal weight.

\section{Locomotor Activity Measurements}

Activity was measured in an Accuscan activity monitor (Accuscan Instruments, Columbus, $\mathrm{OH}$ ) and was performed as described previously (Bohn et al, 2003). In brief, locomotor activity was measured at 5-min intervals, and data were analyzed for the total distance traveled in 5-min increases for $150 \mathrm{~min}$. Drugs were administered at various time points depending on the experimental paradigm and are described in the figure legends.

\section{Immunoprecipitation and Western Blot Studies}

Mice were injected with morphine $(20 \mathrm{mg} / \mathrm{kg})$ and then killed 60 min later. The striatum (caudate) was isolated using a rapid head-freeze dissection technique as described previously (Beaulieu et al, 2005). Tissue samples were manually digested in cold $1 \%$ Triton X-100 lysis buffer, and lysates were incubated overnight with immobilized antipERK 1/2 beads (Cell Signaling Technology) for coimmunoprecipitation (co-IP) studies. Beads were washed thoroughly, boiled in Laemmli buffer, and co-immunoprecipitated proteins were analyzed by western blot. For western blot analysis, the immunoprecipitated proteins were loaded into $10 \%$ SDS-PAGE gels (Invitrogen), transferred onto nitrocellulose membranes, and incubated with antibodies to $\beta$ arr2 (gift from Dr RJ Lefkowitz, Duke University), DARPP-32, and pERK 1/2 (Cell Signaling Technology) to determine interactions with pERK. Blots were developed using the LICOR detection system (Licor Biosciences, Lincoln, NE). $\beta$ arr2 band intensity was measured using NIH ImageJ software and was normalized to pERK 1/2 intensity, which was used as a loading control.

\section{Conditioned Place Preference}

A conditioned place preference (CPP) apparatus from Med Associates (St Albans, VT) was used to analyze place preference to morphine in mice and was performed as described previously (Bohn et al, 2003). In brief, the CPP procedure consisted of day 1 of pre-conditioning (pre-test), wherein mice were allowed to move freely between all chambers of the CPP apparatus and the time spent (basal preference) in each chamber was recorded for $30 \mathrm{~min}$. In the conditioning phase, mice were injected with morphine ( 3 or $6 \mathrm{mg} / \mathrm{kg}$ ) on days 2,4 , and 6 and with saline (Sal) on days 3 , 5 , and 7 , and the drug was randomly paired with alternating compartments, such that half of the mice received drug in the black compartment and the other half in the white compartment. On day 8, the test day (test), mice were handled similar to the pre-conditioning day and allowed to move freely between all chambers, and the time spent (drug-induced preference) in each chamber was recorded for $30 \mathrm{~min}$. The data were analyzed by calculating the difference $(\Delta)$ in time spent in the drug-paired chamber on the pre-test and test days.

\section{Statistical Analyses}

Data were analyzed by a standard two-way ANOVA test for comparison between genotypes, treatments, or doses. Individual genotypes, treatments, or doses were compared using a post hoc Tukey's test. Data are presented as mean \pm SEM.

\section{RESULTS}

\section{Role of $\beta$-Arrestins in Morphine-Induced Locomotor Activation}

$\beta$-Arrestins have two major isoforms, 1 and 2 , and both have redundant and specific physiological roles (DeWire 


\section{亭}
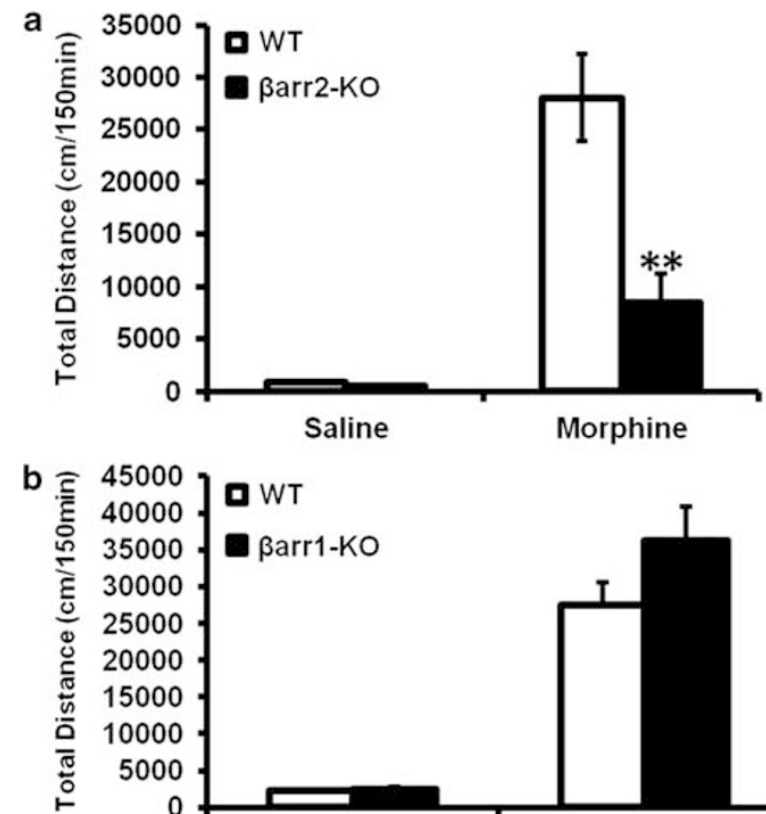

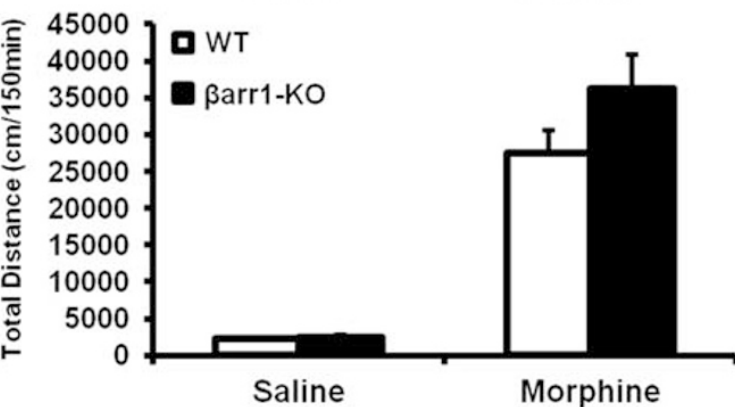

Figure I $\beta$-Arrestin2 but not $\beta$-arrestin I is required for morphineinduced locomotion. (a) Wild-type (WT) and $\beta$-arrestin2 knockout ( $\beta$ arr2-KO) or (b) WT and $\beta$-arrestin I knockout ( $\beta$ arrl-KO) littermates were habituated in an activity monitor for $30 \mathrm{~min}$ and then injected with morphine $(20 \mathrm{mg} / \mathrm{kg}, \quad$ s.c.), and the total cumulative distance traveled $(\mathrm{cm})$ was recorded for an additional $120 \mathrm{~min}$. On morphine stimulation, $\beta$ arr2-KO mice but not $\beta$ arrl-KO mice show significantly decreased distance traveled as compared with WT littermates. $* * * 0.01$, compare WT morphine with $\beta$ arr2-KO morphine. $n=8$ for all treatment groups.

et al, 2007). Previously, it was shown that $\beta$ arr2 is required for morphine-induced locomotor activity (Bohn et al, 2003), but the role of $\beta$ arr1 was not determined. We first confirmed the previously published result that $\beta$ arr2 is indeed required for morphine-induced locomotion. Locomotor activity of WT and $\beta$ arr2-KO mice was analyzed for an initial 30-min habituation period after which morphine $(20 \mathrm{mg} / \mathrm{kg}$, s.c.) was administered and activity analyzed for an additional $120 \mathrm{~min}$. In this study, we chose to use a $20 \mathrm{mg} / \mathrm{kg}$ dose of morphine as it elicits a robust locomotor response, which is significantly blunted in Barr2-KO mice (Bohn et al, 2003), but does not show a differential gastrointestinal or respiratory suppression response between the two genotypes (Raehal et al, 2005). WT mice showed a robust time-dependent increase in locomotor activity after morphine administration $(20 \mathrm{mg} / \mathrm{kg}$, s.c.), which was blunted in $\beta$ arr2-KO mice (Supplementary Figure S1). As observed before, morphineinduced cumulative distance traveled over a period of $150 \mathrm{~min}$ was significantly decreased in $\beta$ arr2-KO mice than in WT littermate controls (Figure 1a). However, in $\beta$ arr1-KO mice, morphine-induced $(20 \mathrm{mg} / \mathrm{kg}$, s.c.) locomotor activity was not significantly different than in WT littermate controls (Figure $1 \mathrm{~b}$ ), even at lower doses (data not shown). These data suggest that $\beta$ arr2 is the major isoform that regulates morphine-induced locomotor activity and that $\beta$ arr1 does not compensate for the loss of $\beta$ arr2 function.

\section{ERK is Required for Morphine-Induced Locomotor Activity}

Previous work from our laboratory has suggested a role for a $\beta$ arr2/AKT/GSK3 signaling complex in amphetamineinduced locomotion in mice (Beaulieu et al, 2005). Therefore, we asked the question whether this signaling complex could also regulate morphine-induced locomotor activity. We used both genetic and pharmacological manipulation of GSK3 $\beta$ to answer this question. In mice that are heterozygote for the GSK3 $\beta$ gene (GSK3 $\beta+/-$ ) or WT mice systemically treated with the GSK3 inhibitor TDZD, amphetamine-induced locomotor activity is inhibited (Beaulieu et al (2004) and Supplementary Figure S2c). Surprisingly, morphine-induced locomotion was not inhibited in either GSK3 $\beta+/-$ mice (Supplementary Figure S2a) or WT mice treated with TDZD (30 mg/kg, i.p.) (Supplementary Figure S2b) compared with their vehicle controls. However, morphine-induced locomotion was increased in GSK $3 \beta+1-$ mice (Supplementary Figure $\mathrm{S} 2 \mathrm{~b})$. These results suggest that the $\beta$ arr2/AKT/GSK3 signaling complex may not have a major role in the regulation of morphine-induced locomotor activity.

Several studies have shown an important role for ERK signaling in the behavioral effects of morphine (Liu et al, 2007; Valjent et al, 2006ab). We asked whether ERK signaling might be involved in the regulation of morphine-induced locomotor activity. To answer this question, we used the MEK inhibitor SL327, which has been shown to inhibit ERK activity in the brain (Beaulieu et al, 2006). WT mice were pre-treated with SL327 for $15 \mathrm{~min}$ after which they were administered an acute dose of morphine $(20 \mathrm{mg} /$ $\mathrm{kg}$, s.c.) and their locomotor activity was measured. SL327 inhibited morphine-induced locomotor activity in a dosedependent manner (Figure 2b), suggesting a role for ERK signaling in the locomotor effects of morphine.

\section{Acute Morphine Administration Leads to Formation of a $\beta$-arr2/pERK Signaling Complex}

$\beta$-Arrestins have been shown to scaffold signaling complexes and engage a mode of signaling that is distinct from $G$ protein-mediated signaling both in terms of kinetics and spatial pattern (Lefkowitz and Shenoy, 2005). In particular, $\beta$-arrestins have been shown to scaffold ERK signaling complexes, which have distinct physiological outcomes compared with $\mathrm{G}$ protein-mediated signaling (Ahn et al, 2004; Wei et al, 2004). As morphine-induced locomotor activity is inhibited in $\beta$ arr2-KO mice and by MEK/ERK inhibition, we therefore asked whether $\beta$ arr2/ERK signaling complexes are formed during morphine-induced locomotion and also whether this complex might mediate this behavior. WT mice were acutely administered with morphine $(20 \mathrm{mg} / \mathrm{kg}$, s.c.), and $60 \mathrm{~min}$ later the brains were processed for co-IP of $\beta$ arr2/ERK complexes (see the 'Materials and methods' section). As shown in Figure 3, morphine administration results in a three-fold increase in the formation of the $\beta$ arr $2 / \mathrm{pERK}$ complex over basal, but DARPP-32 does not co-immunoprecipitate with pERK. These results suggest that morphine regulates $\beta$ arr $2 / \mathrm{pERK}$ signaling complexes in the striatum, which may have a role in morphine-induced locomotor activity and that DARPP32 is not involved in this $\beta$-arrestin signaling complex. 

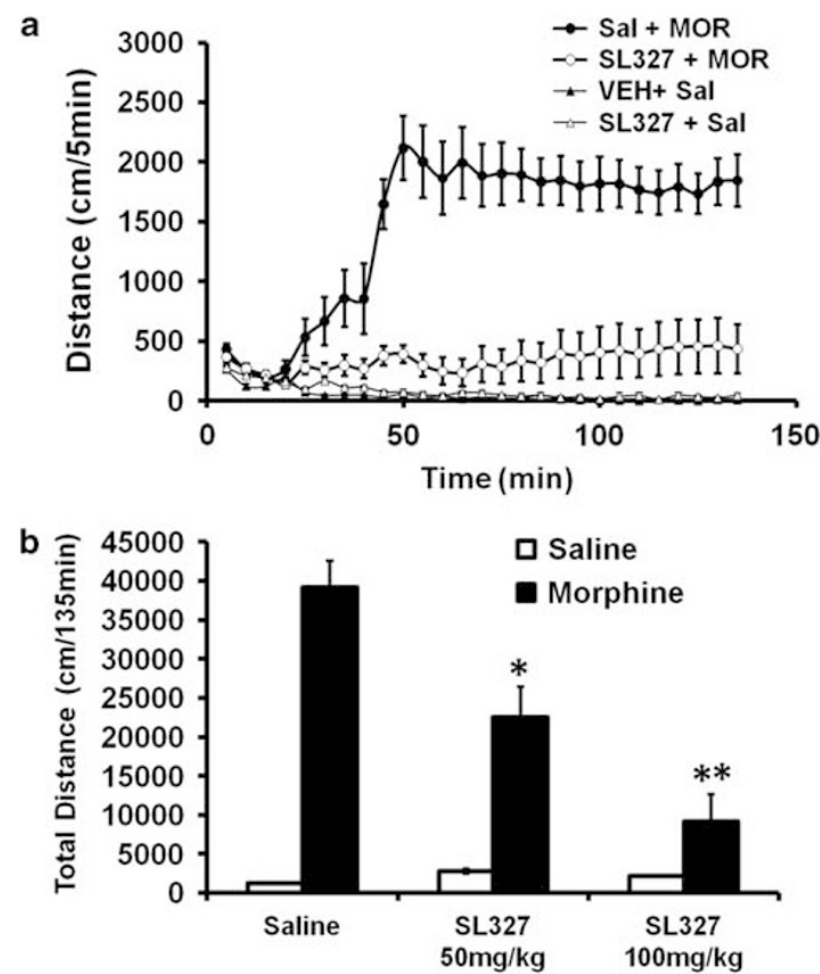

Figure 2 ERK is required for morphine-induced locomotion. (a) Wildtype mice were injected with either saline (Sal) or the MEK inhibitor SL327 ( $100 \mathrm{mg} / \mathrm{kg}$, i.p.) and placed in an activity monitor, and the distance traveled was recorded every $5 \mathrm{~min}$ for $15 \mathrm{~min}$ and then injected with morphine (Mor) $(20 \mathrm{mg} / \mathrm{kg}$, s.c.) and the distance traveled was recorded every $5 \mathrm{~min}$ for 120 min. $n=8$ for all treatment groups. (b) Total cumulative distance recorded for $135 \mathrm{~min}$ for either saline or different doses of SL327 (50 and $100 \mathrm{mg} / \mathrm{kg}$, i.p.), followed by morphine administration. * $p<0.05$; $* * 2<0.0$ I, compare Sal + Mor treatment with SL327 + Mor treatments (black bars).

\section{D1 Receptors are Required for $\beta$-Arrestin Signaling Complex Formation}

Some studies have implicated D1 dopamine receptors in mediating morphine-induced locomotor activity (Becker et al, 2001; Borgkvist et al, 2007). D1 receptors activate the canonical PKA/DARPP-32 pathway through coupling to $\mathrm{G} \alpha$ s that activates adneylate cyclase leading to cAMP accumulation (Greengard, 2001; Missale et al, 1998). Therefore, we examined whether D1 receptors were required for $\beta$-arrestin-dependent locomotion induced by morphine. To investigate this question, we initially tested the ability of morphine to induce locomotor activity in D1KO mice. D1-KO mice and their WT littermates were injected acutely with morphine at different doses (Figure 4a and $\mathrm{b}$ ). WT mice displayed a robust locomotor response to morphine at doses of 5,10 , and $20 \mathrm{mg} / \mathrm{kg}$ s.c., whereas D1KO mice displayed a significantly blunted response at all three doses (Figure 4b). Similarly, acute inhibition of D1R function using the receptor antagonist SCH23390 resulted in the inhibition of morphine-induced locomotion (Supplementary Figure S3, black bars). To further address the question whether D1 receptors regulate morphine-induced locomotion in a $\beta$-arrestin-dependent manner, we performed co-IPs of pERK and $\beta$ arr2 in control (WT) and D1-KO mice. As shown in Figure 5, pERK and $\beta$ arr2 a
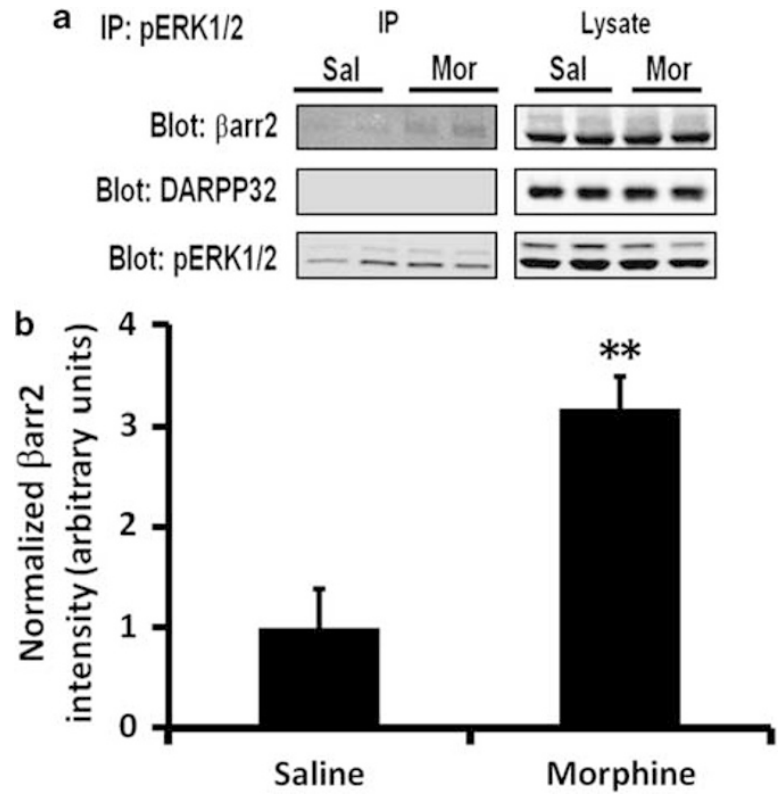

Figure $3 \beta$-Arrestin2 and pERK form a complex on morphine stimulation. (a) Immobilized pERK antibody agarose beads were mixed with striatal lysates from saline $(S a l, n=6)$ or morphine (Mor, $n=6$ ) (20 mg/kg, s.c.), injected into C57Bl/6 W WT mice, and subjected to western blot as described in the 'Materials and methods' section. Membranes were probed with antibodies to $\beta$ arr2, DARPP-32, and pERK. The left-side panel represents the immunoprecipitated protein and right panel the total lysates. (b) $\beta$ arr2 band intensity was quantified using Image and normalized to pERK (loading control) band intensity. ${ }^{*} * x<0.0 \mathrm{I}$, compare saline with morphine.

co-immunoprecipitated together in WT (1.5-fold over saline) but not in D1-KO mice, suggesting a role for D1 receptors in mediating morphine-induced $\beta$ arr $2 / p E R K$ complex formation. As a control, we also assessed the effect of inhibition of D2 receptor function on morphine-induced locomotion using both genetic and pharmacological approaches. Surprisingly, morphine-induced locomotion was also significantly reduced in either D2-KO mice compared with their WT littermates (Figure 4c) or by administration of the D2R antagonist raclopride to WT mice (Supplementary Figure S3, gray bars). However, as the function of the pre-synaptic D2 receptor is also inhibited in both D2-KO mice and WT mice treated with raclopride, the reduction of morphine-induced locomotion in these mice could be a result of a dysregulation of pre-synaptic D2 receptor function and subsequent DA release (Rouge-Pont et al, 2002). Furthermore, ablation of only the post-synaptic D2 long isoform in mice (D2L-KO) does not alter the locomotor-inducing effects of morphine (Smith et al, 2002). Taken together, these studies suggest that $\mathrm{D} 2$ receptors may not have a critical role in morphine-induced locomotion. To further investigate the exact contribution of D2 receptors in morphine-induced locomotion, we used DAT-KO mice. DAT-KO mice have elevated extracellular levels of DA due to the absence of DA uptake by DAT and exhibit hyperlocomotion (Giros et al, 1996). In addition, these mice have a loss of pre-synaptic D2 receptor function (Jones et al, 1999), making them an ideal model to assess the postsynaptic D2 receptor contribution to morphine-induced 

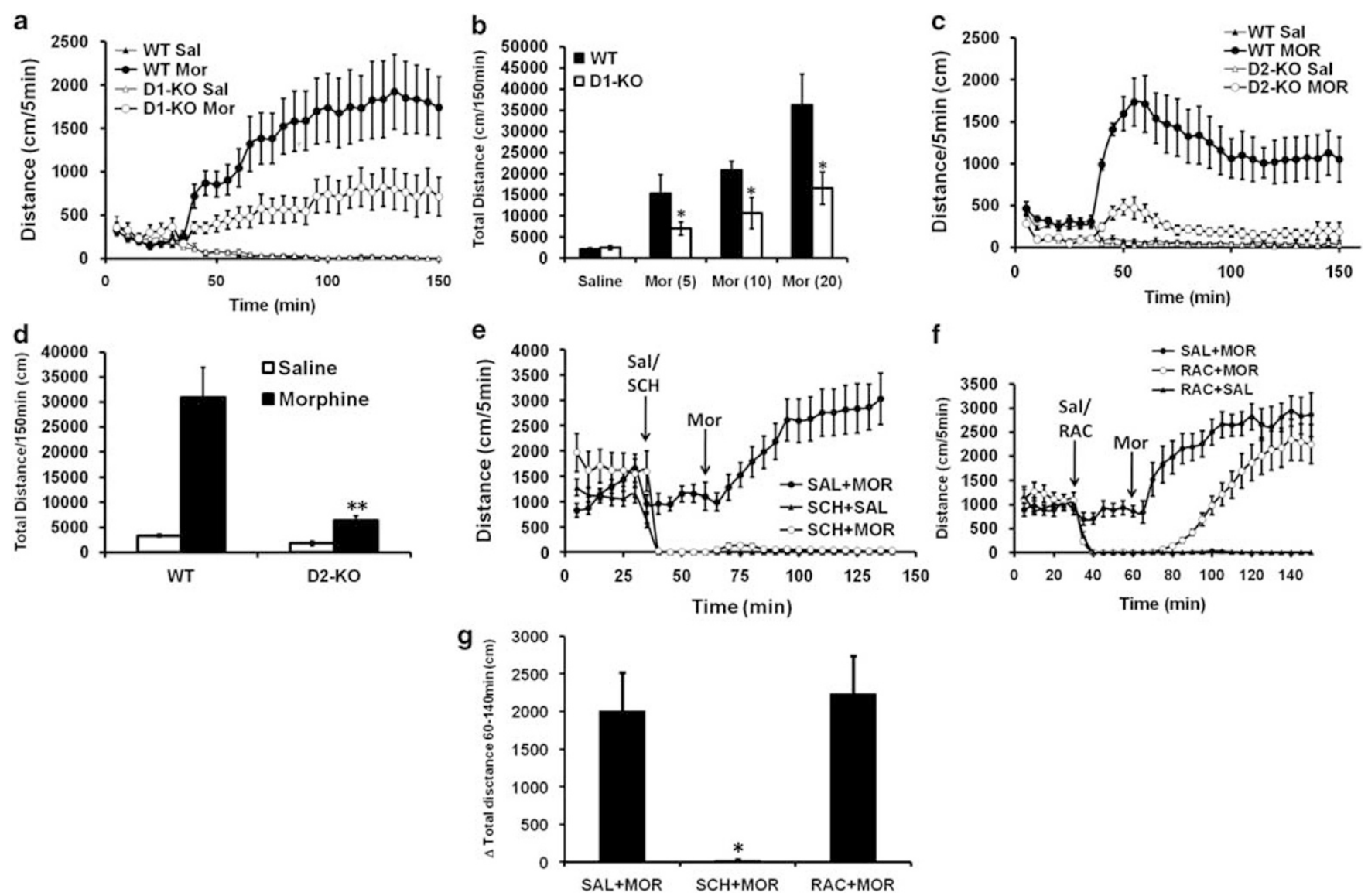

Figure 4 DI receptors regulate morphine-induced locomotion. (a) Wild-type (WT) and DI receptor knockout (DI-KO) or (c) WT and D2 receptor knockout (D2-KO) littermates were habituated in an activity monitor, and the distance traveled was recorded every 5 min for 30 min and then injected with morphine (Mor) $(20 \mathrm{mg} / \mathrm{kg}$, s.c.), and the distance traveled was recorded every 5 min for 120 min. On morphine stimulation, DI- and D2-KO mice show significantly decreased distance traveled as compared with WT littermates. $n=8$ for all treatment groups. (b) Total cumulative distance for WT and DI-KO or (d) WT and D2-KO was recorded for $150 \mathrm{~min}$ at 5, 10 , and $20 \mathrm{mg} / \mathrm{kg}$, s.c., for DI mice and $20 \mathrm{mg} / \mathrm{kg}$, s.c., for D2 mice. $\mathrm{DI}-\mathrm{KO}$ and D2KO mice have decreased locomotor activity at all tested doses of morphine. $* 0<0.05$; $* *$ * $<0.0 \mathrm{I}$, compare morphine treatment between genotypes. To test the role of post-synaptic D2 receptors in morphine-induced locomotion, DAT-KO mice were placed in activity monitors and the distance traveled was recorded every $5 \mathrm{~min}$ for $30 \mathrm{~min}$. Mice were then injected with either (e) saline or SCH23390 (0.I mg/kg, s.c.) or (f) saline or raclopride $(2 \mathrm{mg} / \mathrm{kg}$, i.p.) and activity recorded for another $30 \mathrm{~min}$. All treatment groups (panels e and f) were then injected with morphine (Mor) $20 \mathrm{mg} / \mathrm{kg}$, s.c., and activity recorded for additional $60 \mathrm{~min}$. SCH but not RAC blocked the morphine-induced locomotion in DAT-KO mice. (g) Absolute change $(\Delta)$ in the total distance traveled on morphine exposure between time points 60 and I 40 min for various treatments as shown in the figure. $* p<0.0$ I, compare SAL + MOR with $\mathrm{SCH}+\mathrm{MOR}$.

locomotion. DAT-KO mice were placed in the activity monitor for $30 \mathrm{~min}$ where they exhibited hyperactivity on exposure to the novel environment. After the 30 -min initial period, mice were then injected with saline (Sal), a D1 (SCH23390), or D2 (raclopride) receptor antagonist. Administration of either antagonist but not saline inhibited the hyperactivity of DAT-KO mice. Thirty minutes later, these mice were then injected with morphine $(20 \mathrm{mg} / \mathrm{kg}$, s.c.). Previous administration of SCH23390 (Figure 4e) but not raclopride (Figure 4f) blocked morphine-induced locomotion in DAT-KO mice. Furthermore, as seen in Figure 4g, SCH23390 but not raclopride administration blocks the absolute increase in morphine-induced locomotion as calculated by the difference in total distance traveled $(\Delta)$ between 60 and $140 \mathrm{~min}$ (SAL + MOR: $844-2861=2017$; RAC + MOR: $4-2245=2241, p=0.741$ and $\mathrm{SCH}+\mathrm{MOR}$ : $28-2=26, p=0.002)$. These results suggest that postsynaptic D2 receptors may not be required for morphine- induced locomotion, consistent with the data obtained with D2L-KO mice.

\section{D1 Receptors are Not Required for the Rewarding Properties of Morphine}

Previous work from our laboratory has shown that $\beta$ arr2 is not required for morphine locomotor sensitization, whereas CPP to morphine was increased in $\beta$ arr2-KO mice than in WT littermates (Bohn et al, 2003). Interestingly, in D1-KO mice, sensitization to morphine is inhibited (Becker et al, 2001). Therefore, we examined whether D1-KO mice could experience the rewarding effects of morphine. To answer this question, we assessed the ability of WT and D1-KO mice to show place preference to morphine. Surprisingly, both WT and D1-KO mice showed morphine-induced CPP at doses of 3 and $6 \mathrm{mg} / \mathrm{kg}$ s.c. (Figure 6). These and previous 
a

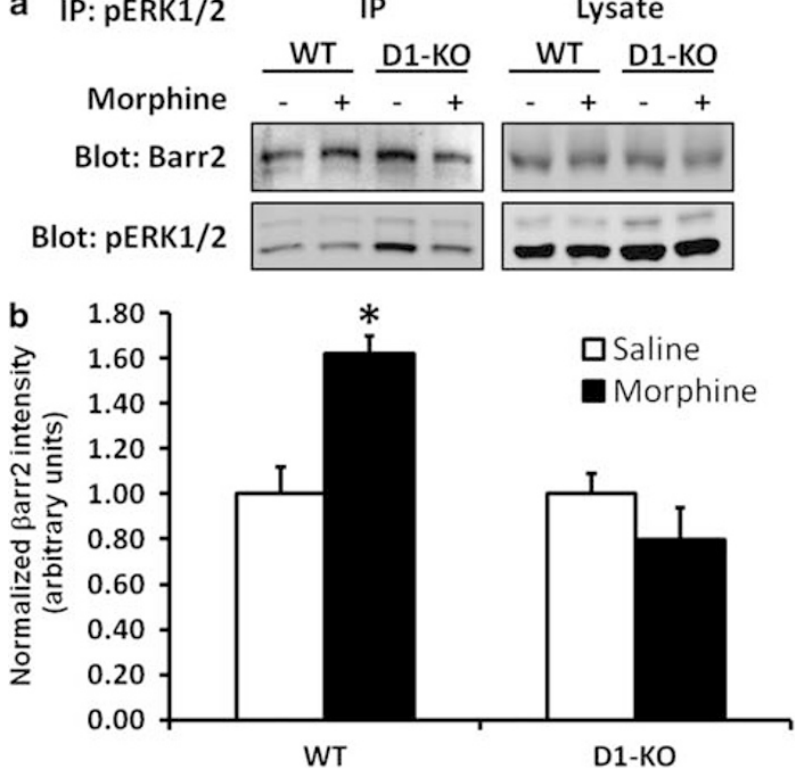

Figure 5 DI receptors are required for $\beta$-arr2/pERK complex formation (a) Wild-type (WT) and DI-KO mice were injected with either saline (Sal, $n=4$ ) or morphine (Mor, $n=5$ ) for $60 \mathrm{~min}$ and striata were rapidly dissected out. Immobilized pERK antibody agarose beads were mixed with striatal lysates and subjected to western blot as described in Figure 2 and in the 'Materials and methods' section. (b) Quantification of $\beta$ arr2 band intensity normalized to pERK intensity. On morphine (Mor) stimulation, WT mice show a $\sim 1.5$-fold increase in $\beta$ arr 2 interaction, which is absent in $\mathrm{DI}-\mathrm{KO}$ mice. ${ }^{*} p<0.05$, compare saline with morphine.

data suggest that D1 receptors or $\beta$ arr2 are not required for expression of the rewarding properties of morphine.

\section{DISCUSSION}

$\beta$-Arrestins are classically known to mediate desensitization and internalization of receptors, but recently they have been shown to promote $G$ protein-independent signaling through their ability to scaffold various signaling molecules (Beaulieu et al, 2009; Lefkowitz and Shenoy, 2005). Previously, we have shown that in $\beta$ arr2-KO mice, the analgesic and rewarding properties of morphine are enhanced, suggesting a role for the desensitizing function of $\beta$ arr2 in limiting these responses (Bohn et al, 1999, 2003). Interestingly, the locomotor-enhancing effects of morphine are blunted in $\beta$ arr2-KO but not in $\beta$ arr1-KO mice (Figure 1), suggesting a role for $\beta$ arr2-dependent signaling in the regulation of morphine-dependent locomotion. In this study, we sought to determine the molecular mechanism of this $\beta$ arr2-dependent morphine-induced locomotor activity. We show that $\beta$ arr2 interaction with pERK increases in the striatum on morphine stimulation (Figure 3) and that this $\beta$ arr $2 /$ pERK signaling complex may mediate morphine-induced locomotion. Previous studies from our laboratory with $\beta$ arr2-KO mice have shown a role for a $\beta$ arr2/AKT/GSK3 $\beta$ signaling complex that mediates DAdependent behaviors, such as locomotion (Beaulieu et al, 2005). Although we show that morphine-induced locomotion does not require GSK3 $\beta$, an important point to be noted is that studies showing a role for $\beta$ arr2/AKT/GSK3 $\beta$

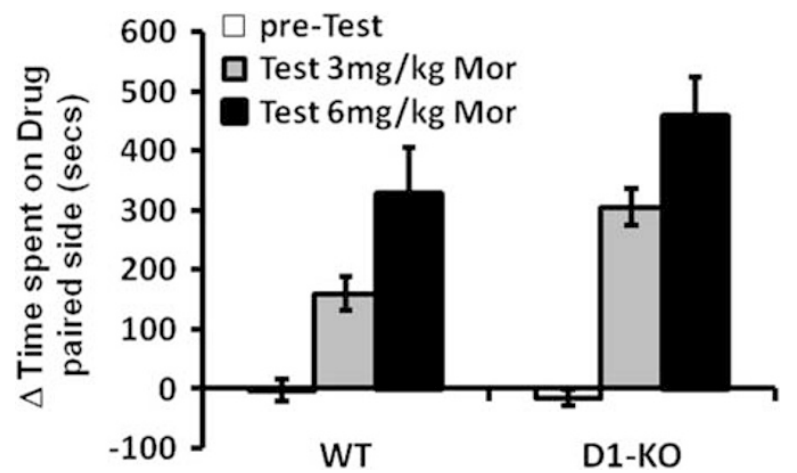

Figure 6 DI receptors are not required for morphine-induced place preference Wild-type (WT) and DI-KO mice were assessed for the time spent in either black or white compartment on the pre-conditioning day. Morphine was randomly paired with either compartment for both genotypes as described in the 'Materials and methods' section. After the sixth day of conditioning phase (see the 'Materials and methods'), time spent in either compartment was assessed on day 8 (post-conditioning or test phase). Data are represented as difference in time spent in the drugpaired chamber on the pre- and post-conditioning days. Morphine at $3 \mathrm{mg} /$ $\mathrm{kg}$, s.c. (gray bars) and $6 \mathrm{mg} / \mathrm{kg}$ s.c. (black bars) induced significant place preference $(p<0.0 \mathrm{I})$ in both WT and DI-KO mice, without any significant difference between genotypes. $n=12$ for all groups.

in DA-dependent behaviors were conducted with amphetamine and thus could represent the activation status of different receptors as compared with morphine stimulation. Amphetamine-induced $\beta$-arrestin complex formation requires mostly D2 receptors (Beaulieu et al, 2007), whereas morphine-induced complex formation primarily requires D1 receptors (Figures 4 and 5).

$\beta$-Arrestins are known to scaffold MAPK signaling molecules to mediate ERK activation (Wei et al, 2004). Although ERK is required for previously learned place preference induced by cocaine and morphine (Valjent $e t$ al, 2006a), it is not required for acute locomotor effects of amphetamine and cocaine as shown by inhibiting ERK activation using the MEK inhibitor SL327 (Valjent et al, 2006b). However, amphetamine-induced locomotion can be inhibited by administration of high doses of SL327 (Beaulieu et al, 2006), suggesting that ERK signaling might have a role in the acute locomotor effects of certain psychostimulants. Unexpectedly, morphine-induced locomotion is also inhibited by SL327 administration in a dosedependent manner (Figure 2) consistent with a $\beta$ arr2/pERK signaling complex mediating morphine-induced locomotion. Interestingly, even at high doses of SL327 (50 and $100 \mathrm{mg} / \mathrm{kg}$ ), cocaine-induced hyperlocomotion is not significantly inhibited (data not shown), highlighting the specificity of the inhibition of morphine-induced locomotion. Furthermore, this $\beta$ arr2/pERK complex does not form in D1-KO mice on morphine stimulation and morphineinduced locomotion is significantly inhibited in D1-KO mice in a dose-dependent manner (Figures 4 and 5). Our results are consistent with previous findings that the D1 receptor forms a complex with pERK and $\beta$ arr2 in cultured SK-N-MC neuroblastoma cells (Chen et al, 2004). Thus, collectively, these data suggest that a D1R/ $\beta$ arr2/pERK complex may mediate morphine-induced locomotion.

A previous study by Becker et al (2001) showed that D1 receptors are critical for developing locomotor sensitization 
to morphine in mice. Locomotor sensitization is presumably related to the rewarding properties of a drug but surprisingly D1 receptors are not required for $\mathrm{CPP}$ to morphine (Figure 6), suggesting that D1 receptors are required for acquisition of sensitization but not for the expression of reward in CPP. In addition, Becker et al (2001) also showed that $\mu$-opioid receptor expression in the striatum of $\mathrm{D} 1-\mathrm{KO}$ mice is reduced. The $\mu$-opioid receptors are expressed on both MSNs of the striatum and on GABAergic interneurons of the midbrain. Although the ability of morphine to enhance the release of DA from midbrain DA neurons is presumably required for striatal D1R activation, the exact contribution of striatal $\mu$-opioid receptors to the locomotor effects of morphine is not known. Interestingly, Juhasz et al (2008) showed in HEK cells that $\mu$-opioid and D1 receptors form hetero-oligomers and that $\mu$-opioid receptor expression was increased in the presence of D1 receptors and this effect required the Cterminal region of the D1 receptor. Therefore, it is possible that D1 and $\mu$-opioid receptors in the striatum work in concert to mediate the effects of morphine. In addition, a study by Zhang et al (1998) showed that $\mu$-opioid receptors that normally do not recruit $\beta$-arrestins on morphine stimulation can recruit $\beta$ arr2 on overexpression of GRK2. However, Haberstock-Debic et al (2005) have shown that unlike HEK cells, morphine stimulation can lead to $\mu$-opioid receptor binding to $\beta$-arr2 and internalization in rat striatal neurons. Therefore, it is also possible that D1 receptors in the striatum act as a GRK/ $\beta$-arrestin recruitment-promoting agent for the $\mu$-opioid receptor. Thus, in addition to the ability of morphine to release DA from midbrain neuron projections, a possible scenario is that simultaneous binding of morphine to $\mu$-opioid receptors and that of DA to D1 receptors in the striatum results in morphine-dependent $\beta$-arrestin signaling. It would be interesting to study the effect of selective ablation of $\mu$-opioid receptors in D1 receptor expressing MSNs of the striatum. If indeed the D1 and $\mu$-opioid receptors heterodimerize in vivo and are both required in MSNs for morphine-induced locomotion, then one would expect that deletion of the $\mu$-opioid receptor in D1 expressing MSNs would lead to inhibition of morphine-induced locomotion, without altering the rewarding or analgesic properties of morphine.

Taken together, these data provide evidence for the formation of a $\beta$ arr2/pERK signaling complex mediated by the activation of the $\mathrm{D} 1$ receptor that may potentially have a role in regulating morphine-induced locomotion. However, this D1R and $\beta$ arr2-dependent signaling pathway does not have a role in the rewarding properties of morphine highlighting a functional selectivity (Urban et al, 2007) of signaling pathways at these receptors.

\section{ACKNOWLEDGEMENTS}

This work was supported in part by the National Institutes of Health, grant numbers RO1-MH-0753 and U-19-MH082441. We thank Wendy Roberts, Xiuqin Zhang, and Katherine Harley for maintenance of the mouse colony. D2 DA receptor knockout mice were generously provided by Dr Malcolm J Low at the Oregon Health and Science University in Portland, Oregon. D1 DA receptor mice were generously provided originally by Dr John Drago (NIH). GSK3 $\beta+1-$ mice were generously provided by $\mathrm{Dr}$ James Woodgett at the Samuel Lunenfeld Research Institute, Toronto, Canada.

\section{DISCLOSURE}

MGC owns stock of Acadia Pharmaceutical. He has consulted and received compensation from Lundbeck, Roche, and Merck. He has also received compensation in the form of honoraria for lecturing at various scientific meetings and academic institutions. None of the above presents any conflicts of interest with the results being described in this paper. Other authors have no disclosures/ conflicts of interest.

\section{REFERENCES}

Ahn S, Shenoy SK, Wei H, Lefkowitz RJ (2004). Differential kinetic and spatial patterns of beta-arrestin and $G$ protein-mediated ERK activation by the angiotensin II receptor. J Biol Chem 279: 35518-35525.

Beaulieu JM, Gainetdinov RR, Caron MG (2009). Akt/GSK3 signaling in the action of psychotropic drugs. Annu Rev Pharmacol Toxicol 49: 327-347.

Beaulieu JM, Sotnikova TD, Gainetdinov RR, Caron MG (2006). Paradoxical striatal cellular signaling responses to psychostimulants in hyperactive mice. J Biol Chem 281: 32072-32080.

Beaulieu JM, Sotnikova TD, Marion S, Lefkowitz RJ, Gainetdinov RR, Caron MG (2005). An Akt/beta-arrestin 2/PP2A signaling complex mediates dopaminergic neurotransmission and behavior. Cell 122: 261-273.

Beaulieu JM, Sotnikova TD, Yao WD, Kockeritz L, Woodgett JR, Gainetdinov RR et al. (2004). Lithium antagonizes dopaminedependent behaviors mediated by an AKT/glycogen synthase kinase 3 signaling cascade. Proc Natl Acad Sci USA 101: 5099-5104.

Beaulieu JM, Tirotta E, Sotnikova TD, Masri B, Salahpour A, Gainetdinov RR et al. (2007). Regulation of Akt signaling by D2 and D3 dopamine receptors in vivo. J Neurosci 27: 881-885.

Becker A, Grecksch G, Kraus J, Peters B, Schroeder H, Schulz S et al. (2001). Loss of locomotor sensitisation in response to morphine in D1 receptor deficient mice. Naunyn Schmiedebergs Arch Pharmacol 363: 562-568.

Bohn LM, Gainetdinov RR, Sotnikova TD, Medvedev IO, Lefkowitz RJ, Dykstra LA et al. (2003). Enhanced rewarding properties of morphine, but not cocaine, in beta(arrestin)-2 knock-out mice. J Neurosci 23: 10265-10273.

Bohn LM, Lefkowitz RJ, Caron MG (2002). Differential mechanisms of morphine antinociceptive tolerance revealed in (beta)arrestin-2 knock-out mice. J Neurosci 22: 10494-10500.

Bohn LM, Lefkowitz RJ, Gainetdinov RR, Peppel K, Caron MG, Lin FT (1999). Enhanced morphine analgesia in mice lacking betaarrestin 2. Science (New York, NY) 286: 2495-2498.

Borgkvist A, Usiello A, Greengard P, Fisone G (2007). Activation of the cAMP/PKA/DARPP-32 signaling pathway is required for morphine psychomotor stimulation but not for morphine reward. Neuropsychopharmacology 32: 1995-2003.

Chen J, Rusnak M, Luedtke RR, Sidhu A (2004). D1 dopamine receptor mediates dopamine-induced cytotoxicity via the ERK signal cascade. J Biol Chem 279: 39317-39330.

Conner DA, Mathier MA, Mortensen RM, Christe M, Vatner SF, Seidman CE et al. (1997). Beta-arrestin1 knockout mice appear normal but demonstrate altered cardiac responses to betaadrenergic stimulation. Circ Res 81: 1021-1026. 
DeWire SM, Ahn S, Lefkowitz RJ, Shenoy SK (2007). Beta-arrestins and cell signaling. Annu Rev Physiol 69: 483-510.

Di Chiara G, Imperato A (1988a). Drugs abused by humans preferentially increase synaptic dopamine concentrations in the mesolimbic system of freely moving rats. Proc Natl Acad Sci USA 85: 5274-5278.

Di Chiara G, Imperato A (1988b). Opposite effects of mu and kappa opiate agonists on dopamine release in the nucleus accumbens and in the dorsal caudate of freely moving rats. J Pharmacol Exp Ther 244: 1067-1080.

Drago J, Gerfen CR, Lachowicz JE, Steiner H, Hollon TR, Love PE et al. (1994). Altered striatal function in a mutant mouse lacking D1A dopamine receptors. Proc Natl Acad SciUSA 91: 12564-12568.

Ferguson SS, Downey III WE, Colapietro AM, Barak LS, Menard L, Caron MG (1996). Role of beta-arrestin in mediating agonistpromoted G protein-coupled receptor internalization. Science (New York, NY) 271: 363-366.

Gainetdinov RR, Premont RT, Bohn LM, Lefkowitz RJ, Caron MG (2004). Desensitization of $G$ protein-coupled receptors and neuronal functions. Annu Rev Neurosci 27: 107-144.

Giros B, Jaber M, Jones SR, Wightman RM, Caron MG (1996). Hyperlocomotion and indifference to cocaine and amphetamine in mice lacking the dopamine transporter. Nature 379: 606-612.

Greengard P (2001). The neurobiology of slow synaptic transmission. Science (New York, NY) 294: 1024-1030.

Haberstock-Debic H, Kim KA, Yu YJ, von Zastrow M (2005). Morphine promotes rapid, arrestin-dependent endocytosis of mu-opioid receptors in striatal neurons. J Neurosci 25: $7847-7857$

Hoeflich KP, Luo J, Rubie EA, Tsao MS, Jin O, Woodgett JR (2000). Requirement for glycogen synthase kinase-3beta in cell survival and NF-kappaB activation. Nature 406: 86-90.

Johnson SW, North RA (1992). Opioids excite dopamine neurons by hyperpolarization of local interneurons. J Neurosci 12: $483-488$

Jones SR, Gainetdinov RR, Hu XT, Cooper DC, Wightman RM, White FJ et al. (1999). Loss of autoreceptor functions in mice lacking the dopamine transporter. Nat Neurosci 2: 649-655.

Juhasz JR, Hasbi A, Rashid AJ, So CH, George SR, O’Dowd BF (2008). Mu-opioid receptor heterooligomer formation with the dopamine D1 receptor as directly visualized in living cells. Eur J Pharmacol 581: 235-243.

Kelly MA, Rubinstein M, Asa SL, Zhang G, Saez C, Bunzow JR et al. (1997). Pituitary lactotroph hyperplasia and chronic hyperprolactinemia in dopamine D2 receptor-deficient mice. Neuron 19: 103-113.
Lefkowitz RJ, Shenoy SK (2005). Transduction of receptor signals by beta-arrestins. Science (New York, NY) 308: 512-517.

Liu Y, Wang Y, Jiang Z, Wan C, Zhou W, Wang Z (2007). The extracellular signal-regulated kinase signaling pathway is involved in the modulation of morphine-induced reward by mPer1. Neuroscience 146: 265-271.

Missale C, Nash SR, Robinson SW, Jaber M, Caron MG (1998). Dopamine receptors: from structure to function. Physiol Rev 78: 189-225.

Raehal KM, Walker JK, Bohn LM (2005). Morphine side effects in beta-arrestin 2 knockout mice. J Pharmacol Exp Ther 314: 1195-1201.

Rouge-Pont F, Usiello A, Benoit-Marand M, Gonon F, Piazza PV, Borrelli E (2002). Changes in extracellular dopamine induced by morphine and cocaine: crucial control by D2 receptors. J Neurosci 22: 3293-3301.

Smith JW, Fetsko LA, Xu R, Wang Y (2002). Dopamine D2L receptor knockout mice display deficits in positive and negative reinforcing properties of morphine and in avoidance learning. Neuroscience 113: 755-765.

Sora I, Takahashi N, Funada M, Ujike H, Revay RS, Donovan DM et al. (1997). Opiate receptor knockout mice define mu receptor roles in endogenous nociceptive responses and morphineinduced analgesia. Proc Natl Acad Sci USA 94: 1544-1549.

Urban JD, Clarke WP, von Zastrow M, Nichols DE, Kobilka B, Weinstein $\mathrm{H}$ et al. (2007). Functional selectivity and classical concepts of quantitative pharmacology. J Pharmacol Exp Ther 320: $1-13$.

Valjent E, Corbille AG, Bertran-Gonzalez J, Herve D, Girault JA (2006a). Inhibition of ERK pathway or protein synthesis during reexposure to drugs of abuse erases previously learned place preference. Proc Natl Acad Sci USA 103: 2932-2937.

Valjent E, Corvol JC, Trzaskos JM, Girault JA, Herve D (2006b). Role of the ERK pathway in psychostimulant-induced locomotor sensitization. BMC Neurosci 7: 20.

von Zastrow M (2004). A cell biologist's perspective on physiological adaptation to opiate drugs. Neuropharmacology 47(Suppl 1): $286-292$.

Wei H, Ahn S, Barnes WG, Lefkowitz RJ (2004). Stable interaction between beta-arrestin 2 and angiotensin type $1 \mathrm{~A}$ receptor is required for beta-arrestin 2-mediated activation of extracellular signal-regulated kinases 1 and 2. J Biol Chem 279: $48255-48261$.

Zhang J, Ferguson SS, Barak LS, Bodduluri SR, Laporte SA, Law PY et al. (1998). Role for $G$ protein-coupled receptor kinase in agonist-specific regulation of mu-opioid receptor responsiveness. Proc Natl Acad Sci USA 95: 7157-7162.

Supplementary Information accompanies the paper on the Neuropsychopharmacology website (http://www.nature.com/npp) 